\title{
Okul öncesi dönem çocukları (36-72 ay) için Özbakım Becerileri Ölçeği-Öğretmen Formu’nun geçerlik ve güvenirlik çalışması
}

\author{
Çağlayan DİNÇER ${ }^{[*]}$ \\ Serap DEMIRIZ[ ${ }^{[*]}$ \\ Ayșegül ERGÜL $L^{[* *]}$
}

\begin{abstract}
Öz
Okul öncesi eğitim kurumları, çocukların yaşamsal bazı becerileri edinmelerini sağlayan ortamlardır. Bu beceriler yemek yeme, giysilerini giyme ve düzenleme, temizlik yapma, tuvalet eğitimi, düzenli olma ve tehlikelerden korunma gibi özbakım becerileridir. Bu çalışmanın ilk bölümünde okul öncesi eğitim kurumlarına devam eden çocukların özbakım becerilerini belirlemek amacıyla "Okul Öncesi Dönem Çocukları (36-72 ay) İçin Özbakım Becerileri Ölçeği-Öğretmen Formu”nun geçerlik ve güvenirlik çalışması yapılmış, ikinci bölümünde ise, öğretmenlerin çocukların özbakımlarıyla ilgili hangi becerileri önemli bulduğu belirlenmeye çalışılmıştır. Çalışma grubu, Ankara ili merkez ilçelerinde yer alan okul öncesi eğitim kurumlarına devam eden 36-72 ay arasındaki 261 çocuktan oluşmaktadır. Elde edilen bulgulara göre, "Okul Öncesi Dönem Çocukları (36-72 ay) İçin Özbakım Becerileri Ölçeği-Öğretmen Formu”nun geçerli ve güvenilir olduğu belirlenmiştir. Öğretmenlerin "Kişisel temizlik-tuvalet” ile ilgili özbakım becerilerini diğerlerine oranla çok daha önemli buldukları saptanmıştır. Bu bulgunun yanı sıra cinsiyet, kardeș varlığı, kuruma tam-yarım gün devam etme ve doğum sırası değişkenleri bakımından özbakım becerilerinde anlamlı farklılık olmadığı ancak çocukların yaşları büyüdükçe ve okul öncesi eğitim kurumuna devam süreleri arttıkça özbakım becerilerini hayata geçirme oranlarının arttığı ortaya çıkmıştır.
\end{abstract}

Anahtar kelimeler: Okul öncesi, özbakım, ölçek geliştirme.

[*] Prof. Dr., Ankara Üniversitesi, Eğitim Bilimleri Fakültesi, Temel Eğitim Bölümü, cdincer@education.ankara.edu.tr

${ }^{\left[{ }^{*}\right]}$ Yrd. Doç. Dr., Gazi Üniversitesi, Gazi Eğitim Fakültesi, Temel Eğitim Bölümü, demiriz@gazi.edu.tr

${ }^{\left[{ }^{*}\right]}$ Arş. Gör., Ankara Üniversitesi, Eğitim Bilimleri Fakültesi, Temel Eğitim Bölümü, ergula@ankara.edu.tr 


\title{
Validity and reliability study of the self-care skills scale-teacher form for pre-school children (36-72 months)
}

\begin{abstract}
Preschools are places where can provide vital skills for children. These skills are eating, wearing and organizing clothes, cleaning, toilet training, organizing and protection from dangers that can be described as self-care skills. The first part of the study covers the validity and reliability of "Preschool Children (36-72 months) Self-Care Skills Scale- Teacher Form" to determine their self-care skills. The second part of the study aims to determine which self-care skills teachers find important. The study group included 261 children aged 36-72 months attending at preschool education institutions in Ankara central districts. According to the findings, Preschool Children (36-72 months) Self-Care Skills Scale- Teacher Form was found to be reliable and valid. Teachers give more importance to the "Self cleaning and toilet training skills" than other self-care skills. Results also showed that any statistically significant difference has not been encountered in the gender, presence of siblings, half-full day attendance of preschool, and birth order variables; but by the children get older and attending time at the preschool education increases, self-care skills implementing rate increases.
\end{abstract}

Keywords: Preschool, self-care, scale development.

\section{Giriş}

İnsan yaşamındaki davranışların becerilere dönüşebilmesi ve doğru alışkanlıklara temel oluşturması, yaşamın erken dönemlerinde verilen desteklerle doğru orantılıdır. Gelişim sürecinde kazanılan bu becerilerden bazıları, kişinin bireysel gelişiminde kendi başına yeterli olmanın yanı sıra, özellikle kaliteli bir yaşam sürmek ve toplum tarafından kabul için de gereklidir. Bu kapsamda "özbakım” becerileri, fiziksel ve psikolojik olarak sağlıklı bir bireyde olması gereken özellikler arasındadır.

Özbakım becerileri, çocuğun temel ihtiyaçlarını (yemek yeme, giyinme, kişisel bakım, tuvalet vb.) yetişkin desteği olmaksızın yapabilme becerisidir. Özbakım becerilerini kazanan çocuk bağımsızlığını kazanır. Dolayısıyla bu beceriler, çocuğun kendi başına karar vermesini kolaylaştırır. Ayrıca, çocuğun kişilik gelişimine katkıda bulunur (Önder, 2003). Özbakım becerileri bir anlamda günlük yaşam becerileridir. Bu beceriler evde, okulda ya da diğer ortamlarda bireyin bağımsız olarak yaşamını sürdürebilmek, kişisel bakım ve görünüşünü koruyabilmek için gerekli olan tüm beceriler olarak tanımlanmaktadır (Varol, 2005). Tek başına yemek yiyebilen ve tuvalet ihtiyacını giderebilen çocuklarla bu becerileri kazanamamış çocuklar arasında belirgin farklılıklar gözlenmektedir. Aynı yaşta olmalarına rağmen bazı çocuklar yemek yeme, tuvalet ve temizlik alışkanlıkları konusunda bağımsız davranırken, bazı çocuklar yetişkine bağımlı olmaktadırlar (Demirtaş, 2001).

Çocuklar yaşam sürecinde, yerine getirilmesi gereken "gelişim ödevleri” olarak bilinen ve birbirinden farklı özellikler taşıyan gelişim dönemlerinden geçerler. Yemek yeme, kendi 
başına giyinebilme, elini yüzünü yıkama gibi özbakım becerileri özellikle üç-altı yaş döneminde gerçekleştirilmesi beklenen gelişim görevleri arasındadır. Erikson’un psiko-sosyal gelişim kuramına göre on ikinci aydan üç yaşına kadar süren ve "bağımsızlığa karşı utanma ve şüphecilik" olarak adlandırılan ikinci evrede, çocukların kendi kendine yemek yeme, eşyaları toplama, giyinme ve soyunma, giysisini seçme çabaları desteklenmelidir. Senemoğlu (2008), çocuklarda kendi kendini kontrol etme becerisinin ve kendine saygının temelinin bu şekilde oluşabileceğini belirtmektedir.

Bebeklikten çocukluğa geçişsürecinde ailelerin beklentilerinde değişiklikler görülür. Bakımına ilişkin temel şartlar sağlanmakla birlikte, artık çocuğun kendi kendine çeşitli davranışları yapabilmesi istenir. Bebeklik döneminde bebeklerin bakımına dair her ayrıntıyı düşünen ve yapan yetişkinler, bir sonraki aşamaya geçildiğinde çocukla birlikte hareket etmeli ve biraz geride durarak rehber olmalıdırlar. Çünkü ilerleyen yaşlarda bu becerilerin hayata geçirilmesinde evde yeterince desteklenmeyen çocukların sorun yaşadığı gözlemlenmektedir. Bu açıdan bakıldığında ailelerin bu konuya verdikleri önem ve tutumlarının çocuklarının bu becerileri kazanmasında doğrudan etkili olduğu bir kez daha görülmektedir.

Çocukların özbakım becerileri ile anne tutumları arasındaki ilişkiyi annelerin değerlendirmesine göre inceleyen Demirtaş (2001), annelerin aşırı koruyucu tutumlarının çocukların özbakım becerilerinin yanı sıra genel ve bazı temel becerilerin gelişimini olumsuz; demokratik tutumlarının ise, olumlu etkilediğini belirtmiştir. Anneleri baskıcı ve otoriter olan yedi yaşındaki çocukların özbakım becerilerinde daha çok anneye bağımlı oldukları görülmüştür. Ayrıca Demiriz ve Dinçer (2000), okul öncesi çocukların özbakım becerilerini annelerin çalışma durumlarına göre incelemişler ve çalışan anne çocuklarının özbakım toplam puanlarının çalı̧mayan anne çocuklarından daha yüksek olduğunu ortaya çıkarmışlardır.

Temiz ve Bayraktar tarafından yapılan çalışmada (2014), okul öncesi kurumlara devam eden çocukların annelerinin mükemmeliyetçilikleri ve özbakım becerileri arasındaki ilişki incelenmiştir. Kendini tehlikelerden koruma, tuvalet kullanımı, temizlik ve düzenlilik alt boyutlarında mükemmeliyetçi annelerin çocuklarının özbakım puanları daha yüksek bulunmuştur.

Okul öncesi dönemde çocuğa kazandırılacak temel alışkanlıklar zamanla, yönlendirmeyle ve özellikle de tekrara bağlı olarak kazanılmış davranışlara dönüşmektedir (Oktay, 2005). Kazandırılan bu temel alışkanlıklar; toplumun bireyi kabul etmesinde önemli bir yere sahiptir. $\mathrm{Bu}$ davranışlar bir defa kazanıldıktan sonra tekrar ve uygulamalarla artık bireyin sürekli kullanacağı becerilere yerini bırakmaktadır (Katz,1999).

Okul öncesi dönemde çocuklara kazandırılması gereken özbakım becerilerinden biri olan yemek yeme konusundaki tutumlar çok erken yaşta ortaya çıkar ve zamanla gelişir. Okul öncesi dönemde çocukların öğrenme yetenekleri çok gelişmiş olduğundan yemek yeme ile ilgili uygun davranışlar anlatılarak ve model olunarak geliştirilmelidir. Çocuğa yemek yeme alışkanlığı kazandırılmaya çalışılırken yemek saatinin sakin, huzurlu bir atmosfer içinde yemek kurallarına uygun davranılarak geçmesine özen gösterilmelidir. Bu durum çocuğun yemek yeme ile ilgili iyi alışkanlıklar kazanmasının yanı sıra, onun kendine güveninin artmasını da sağlayacaktır. 
Bekem, Öztürk, Arslan ve Büyükgebiz (2003), yaşları 1,2 ila 12,9 arasında olan ve iştahsızlık şikâyeti ile başvuran çocukların anneleri ile bir çalışma yapmışlardır. Annelerin \%51,4'ünün çocuğunu çeşitli oyunlarla beslemeye çalıştığı belirlenmiştir. Önerilmeyen bu davranışın iştahsızlığın başlangıç yaşını daha erkene çektiği görülmüştür. Ayrı zamanlarda yemek yiyen, belirli sofra alışkanlığı olmayan ailelerin çocuklarının tümünde üç yaşın altında iştahsızlığın başladığı saptanmıştır. Bu bulgu, gelişim dönemlerinde beslenme önerilerinin titizlikle uygulanmasının önemini vurgulamaktadır. Beslenme sorunu olan çocukların çoğunluğunda bir öğündeki beslenme süresinin ya çok kısa ya da çok uzun olduğu belirlenmiştir. Yemek sırasında televizyon seyretme alışkanlığının oldukça yüksek oranda olduğu, çocukların çoğunun annesi tarafından beslendiği ve kendisi yiyenlerin bir kısmına da annelerinin yardımcı olduğu bulunmuştur. Uygunsuz yeme davranışı olan çocuklarda en sık dile getirilen yakınma ise, çocukların yemek seçmesidir. Bunun yanı sıra çocukların sadece yarısının masada yemek süresince oturdukları da belirlenmiştir.

Ünver tarafından (2004) ve Ünver ve Ünüsan tarafından (2005) okul öncesi eğitim alan 5-6 yaş çocukları ile yapılan iki ayrı araştırmada, besin gruplarına yönelik beslenme eğitim programının çocukların beslenme bilgisi ve davranışlarına etkisi incelenmiştir. Araştırmaların sonucunda, beslenme eğitim programını alan çocukların besin gruplarına ilişkin bilgi düzeylerinde artış olduğu ve eğitim programının çocukların yeterli-dengeli beslenme alışkanlıklarını kazanmalarında destekleyici olduğu bulunmuştur.

Çocukların özbakımıyla ilgili konulardan biri olan giyinme-soyunma, beceri isteyen bir takım davranışların birbiri ardına yapılmasını gerektiren bir uygulamadır. Belirli olgunluğa erişmeden giyinme-soyunma ile ilgili davranışların yapılması çocuktan beklenilmemelidir. Çocukla ilgili diğer davranışlarda olduğu gibi giyinme-soyunma davranışlarının kazandırılmasında da sabırlı olunmalı ve çocuklara gereken destek sağlanmalıdır. Giyim sektörü giysilerde çocukların kendi başına yardım almadan giyinebileceği şekilde kolaylıklar planlamakta, böylelikle yardımsız giyinmeye başlayan çocuklar başarılarıyla övünebilmekte ve güven duyabilmektedirler. Ebeveynleri tarafından bu davranışı desteklenen çocuklar böylelikle bu işi bir sorumluluk olarak görebilmektedir (Goldstein, 2006).

Tuvalet ve temizlik alışkanlıkları, insan sağlığı açısından son derece önemlidir. Bu alışkanlıkların olumlu bir biçimde kazanılması, çocukların bu konudaki ilk izlenimleriyle ilgilidir. Olgunlaşmanın da bu konuda önemli bir rolü vardır (Oktay, 2004). Ebeveyn ve eğitimci tutumları bu becerilerin yerleşmesinde önemli rol oynamaktadır. Çocuğa iyi bir model olmanın yanı sıra onun bu alışkanlıkları ile ilgili davranışlarını gözlemlemek ve gerektiğinde istenilen davranışa yönlendirmek alışkanlıkların kazanılmasını çabuklaştırarak kalıcı olmasını sağlayacaktır. Temizlik alışkanlıklarının kazanılması, çocuğun bebeklik dönemine özgü alışkanlıklarından vazgeçip toplumun onayladığı yeni alışkanlıklar edinilmesine bağlıdır Çocuğun vücudu ve vücut fonksiyonlarına karşı duyarlılığı bu becerilerin çocuk açısından ne denli önemli olduğunu göstermekte ve temizlik, tuvalet vb. becerilerin kazandırılmasında yardımcı olmaktadır.

Kazandırılacak temizlik alışkanlıkları; çocuğun giysilerini ıslatmadan, yardım almadan elini yüzünü yıkamasını, yemekten önce ve sonra ellerini yıkamasını ve kurulamasını, dişlerini 
yardım almadan gün içinde fırçalamasını, hapşırırken eliyle ağzını kapatmasını, burnu aktığında mendille silmesini, kulağını temizlemesini, saçlarını yardım almadan taramasını, banyodan çıktığında saçlarını kurutmasını, giysilerinin kirli ve temiz ayrımını yapmasını içerir (Demiriz ve Dinçer, 2000; Demirtaş, 2001). Geiger, Artz ve diğerleri (2000) okul öncesi çocukların bulaşıcı hastalıklardan korunmasını sağlamak için el yıkamayı öğretmek amacıyla bir program hazırlanmış ve bu programdaki etkinlikler, şarkı söyleyerek, oyunlar oynayarak ve rehber kullanarak gerçekleştirilmiştir. Sonuç olarak, çocukların daha kolay ve eğlenerek öğrendikleri gözlenmiştir.

Tertip-düzen de çocuğa küçük yaşlardan itibaren kazandırılması gereken alışkanlıklardandır. Çocukla kurulan iyi bir iletişimle bu konuda kazandırılmak istenen davranışlara ulaşılabilinir. Okul öncesi dönem çocuğunun belirgin özelliklerinden biri, yetişkinin yaptığı her şeye karşı büyük ilgi duymasıdır. Bu nedenle oyunlarında daha çok yetişkinin günlük yaşamındaki etkinlikleri taklit eder. Çocuk günlük yaşamda yardım etmekten, sofra kurmaktan, toz almaktan vb. büyük zevk alır. Bu tür etkinlikler de çocuğun bu konularda beceri kazanmasını kolaylaştırır.

Okul öncesi dönemde çocuklara özbakım becerileri kazandırılmaya çalışılırken planlanmış oyuna dayalı öğrenme etkinliklerinin önemli olduğu bilinmektedir (Konya, 2007 ve Gazazoğlu, 2007). Ancak çocuklardan yapabileceklerinin çok üstünde beceriler beklenmekte ya da bu becerileri çocukların kendi kendine öğrenilebileceği düşünülmektedir. Ayrıca aileler gereksiz yere endişe ettiklerinden yemek yeme, giysilerini giyme, temizlik, tuvalet, düzen ve tehlikelerden korunma alanlarında çocuklarının yapabilecekleri pek çok davranışı öğretmenlerinden beklemektedirler.

Tehlikeleri fark etme ve tehlikelerden korunma becerisi çocukların yaşamlarının ilk anlarından itibaren gelişmeye başlamaktadır. Çocuklar edindikleri deneyimler ve gelişim özellikleri doğrultusunda bazı tehlikeleri fark edebilmekte ve kendilerini belli oranda koruyabilmektedirler. Akşin ve Tunçeli (2015), çocukların tehlike kavramına ilişkin görüşlerini inceleyen bir araştırmada yapmıştır. Sonuçlar incelendiğinde, çocukların tehlikeli olarak değerlendirdiği durumların çoğunlukla fiziksel ve çevresel tehlike içeren durumlar olduğu görülmüştür. Çocukların okula gelirken (trafik kazaları, araçta yaşayabilecekleri kazalar gibi), okul ortamında ve oyuncakları arasında tehlikeli olarak gördükleri durumlar (bir yerden düşmek, bir şeyin üzerine düşmesi, makas gibi aletlerin yarattı̆̆ı tehlike gibi) incelendiğinde bu durumların yine çoğunlukla fiziksel ve çevresel tehlike içeren durumlar olduğu saptanmıştır. Çocuklar en çok arkadaşları ile oyun oynarken sosyal tehlikeler ile karşılaşabileceklerini ifade etmişlerdir.

Öğretmenler günlük çalışma düzeni sırasında ve kalabalık çocuk grupları ile çalışıken bu becerilerin geliştirilmesi konusunda zorluklar yaşamaktadırlar. Pek çok okul öncesi eğitim kurumu henüz kayıt aşamasında iken çocukların temel özbakım becerilerini kazanmış olmasını şart koşmaktadır. Bununla birlikte, kurumlarda küçük yaşlarda yaşanan sorunların en önemli kaynağı, kuruma gelmeden önce bakım veren yetişkinlerin gerekli özbakım becerilerini çocuklara yeterince kazandıramamış olmasıdır. Bu nedenle öğretmenler özellikle eğitim dönemi başında 
çocukların var olan özbakım becerilerini geliştirmek ve yenilerini kazandırmak için çok çeşitli çalışmalar yapmaktadırlar.

Ülkemizde uygulanan Milli Eğitim Bakanlığı “36-72 Aylık Çocuklar İçin Okul Öncesi Eğitim Programı" kapsamında bütüncül bir yaklaşımla bütün gelişim alanları ile özbakım becerilerinin de kazandırılması amaçlanmıştır. Özbakım becerilerini geliştirme çalışmaları, ilkokula hazırlıkta temel olan beceriler olarak kabul edilmektedir. Program kapsamında 36-72 aylık çocukların kazanması gereken temel özbakım becerileri genel olarak tanımlanmış, kazanım ve göstergeler belirtilmiştir. Programda temizlik, giyinme, yaşam alanlarında gerekli düzenlemeleri yapma, yeterli ve dengeli beslenme, dinlenme, günlük yaşam becerileri için gerekli araç ve gereçleri kullanma, kendini tehlikelerden ve kazalardan koruma ve sağlı̆̆ı ile ilgili önlemler alma kazanımları yer almaktadır (MEB, 2013).

Alanyazında özbakım becerileri hakkındaki araştırmaların genellikle gelişimsel ihtiyaçları olan çocuklarla yapıldığı görülmüştür. Farklı araştırmalarda otizm ve down sendromlu çocukların ince motor becerileri ve özbakım becerileri arasında doğrudan bir ilişki bulunmuştur (Jasmin, 2009; Frank ve Esbensen, 2015). Kelo, Martikainen ve Eriksson (2011), tip bir diyabeti olan çocukların özbakım becerilerinin genel sağlık durumları üzerinde etkili olduğunu belirtmişlerdir. Kruijsen-Terpstra ve arkadaşları tarafından yapılan araştırmada (2015), serebral palsili çocukların özbakım becerilerini geliştirmek için geliştirilen farklı terapi yöntemlerinin olumlu etkilerinden bahsedilmiştir. Serebral palsili çocuklarda büyük kas gelişiminin özbakımla ilişkisini ortaya koyan araştırmalar da bulunmaktadır (Chiarello, Palisano, Bartlett, ve McCoy, 2011; Ketelaar, Gorter, Westers, Hanna ve Verhoef, 2014).

Özbakım becerilerinin eviçindeve eğitimkurumlarında daha düzenlibirşekildegözlemlenmesi ve değerlendirilmesi yaşamsal bir konudur. Çocuğun desteğe ihtiyaç duyduğu becerilerin belirlenerek gereken uygulamaların zamanında yapılması, çocuğun ileride yaşayabileceği pek çok sorunun önüne geçebilir. Geliştirilen bu ölçek sayesinde, 36-72 ay arasındaki çocuklarda hangi özbakım becerilerinin görüldüğü ve önem verilme durumları ortaya çıkartılacak, böylece başta öğretmenler olmak üzere çocuğa bakım veren bütün yetişkinler hangi yaş grubunda çocukların hangi özbakım becerilerine sahip olması gerektiğini bileceklerdir. Bunun yanı sıra eğitimciler çocuklara özbakım becerilerini geliştirebilmeleri için doğru bir şekilde rehberlik edebilecek ve ailelere gerekli olan desteği verebileceklerdir.

\section{Yöntem}

\section{Araştırmanın modeli}

Çalışmada öncelikle okul öncesi eğitim kurumuna devam eden 36-72 ay arasındaki çocukların özbakım alanındaki temel becerilerini belirlemek amacıyla "Okul Öncesi Dönem Çocukları (3672 ay) İçin Özbakım Becerileri Ölçeği-Öğretmen Formu”nun geçerlik ve güvenirlik çalışması yapılmıştır. Yapılan çalışma metodolojik araştırma modelindedir ve Özdamar’a göre (2013) bu model araç geliştirme türünde yapılan araştırmaları da kapsamaktadır. 
Çalışmanın sonraki aşamasında, öğretmenlerin 36-72 ay arasındaki çocukların gelişimleri açısından hangi özbakım becerilerini önemli buldukları belirlenmiştir. En son aşamada ise çocukların cinsiyetleri, yaşları (ay aralığı olarak), doğum sıraları, kardeşi olma ya da olmaması, kuruma devam süreleri ve kuruma yarım ya da tam gün devam etme durumlarının özbakım becerileri üzerindeki etkileri incelenmiştir. Tarama deseninde gerçekleştirilen bu çalışmalar, grubun özelliklerini belirlemek için verilerin toplanmasını amaçlamaktadır (Büyüköztürk, Çakmak, Akgün, Karadeniz ve Demirel, 2010). Creswell’e göre (2013), bir evren içinden seçilen bir örneklem üzerinde yapılan çalışmalar yoluyla evren genelindeki eğilim, tutum veya görüşlerin nicel veya nümerik olarak betimlenmesini sağlayan çalışmalar tarama deseninde yer almaktadır.

\section{Çalışma grubu}

Araştırmanın çalı̧̧ma grubu, Ankara ili merkez ilçelerdeki okul öncesi eğitim kurumlarına devam eden 36-72 ay arasındaki çocuklardan oluşmaktadır. Veriler belirtilen yaş grubundaki çocukların öğretmenleri aracılığıyla elde edilmiştir. Tabakalı örnekleme yöntemi ile her öğretmenden sınıfındaki beşer çocuk için bu ölçekleri doldurması istenmiştir. Öğretmenlere bu seçimi yaparken tarafsız olmaları özellikle hatırlatılmıştır.

Veri toplama aşamasında toplam 585 formun geri dönüşü sağlanabilmiştir. Öğretmenlerin çocukların özbakım becerilerini önem açısından değerlendirme durumlarının incelenmesi, toplanan 585 formdan eksik olarak doldurulan formların çıkartılması sonucu 479 form üzerinden yapılmıştır. Geçerlik ve güvenirlik analizleri ise 585 formdan tam olarak doldurulan 261 form üzerinden yapılmıştır. Özbakım becerilerinin değişkenlere göre değerlendirilmesi yine bu 261 form üzerinden gerçekleştirilmiştir. Ancak bu formlarda değişkenler açısından az da olsa doldurulmayan formlar bulunmaktadır. Analizler bu kayıp veriler çıartıldıktan sonra yapılmıştır.

Çalışma grubunda yer alan çocukların bulundukları ay aralıkları ve cinsiyetleri Tablo 1'de özetlenmiştir.

Tablo 1

Çocukların Ay Aralıkları ve Cinsiyet Durumları

\begin{tabular}{|c|c|c|c|c|c|c|}
\hline \multirow[b]{2}{*}{ Ay Aralıkları } & \multicolumn{2}{|c|}{ Erkek } & \multicolumn{2}{|c|}{$\mathrm{K} 1 \mathrm{z}$} & \multicolumn{2}{|c|}{ Toplam } \\
\hline & $\mathrm{N}$ & $\%$ & $\mathrm{n}$ & $\%$ & $\mathrm{n}$ & $\%$ \\
\hline $36-41$ & 6 & 2.3 & 3 & 1.2 & 9 & 3.5 \\
\hline $42-47$ & 9 & 3.1 & 10 & 3.8 & 19 & 6.9 \\
\hline $48-53$ & 16 & 6.2 & 22 & 8.5 & 38 & 14.6 \\
\hline $54-59$ & 31 & 11.9 & 31 & 11.9 & 62 & 23.8 \\
\hline $60-65$ & 42 & 16.2 & 30 & 11.5 & 72 & 27.7 \\
\hline 66-72 & 33 & 12.7 & 28 & 10.8 & 61 & 23.5 \\
\hline TOPLAM & 137 & 52.3 & 124 & 47.7 & 261 & 100 \\
\hline
\end{tabular}




\section{Bulgular}

\section{Ölçeğin geliştirilme aşamaları}

Ölçeğin ilk hali Demiriz ve Dinçer (2000) tarafından geliştirilmiştir. Bu form, "Portage Kontrol Listesi, Seattle Testi ve Denver II. Gelişimsel Tarama Testi”nin özbakım ile ilgili bölümlerinden yararlanılarak oluşturulmuştur. Sonrasında ölçeğin ilk hali temel alınarak güncelleme yapılmıştır. $\mathrm{Bu}$ sırada var olan maddelerin ifadeleri gözden geçirilmiş, yeni maddeler eklenmiş ve form üç farklı yaş grubu için (36-48 ay için 82 madde, 48-60 ay için 54 madde ve 60-72 ay için 54 madde) ayrı ayrı hazırlanmıştır.

Ölçek, özbakım becerilerinin önem derecesinin (önemli değil-önemli-çok önemli) belirlenmesi için üçlü derece şeklinde oluşturulmuştur. Ölçekte gözlemlenemeyen maddeler için de bir bölüm bulunmakta ve ölçek öğretmenler tarafından doldurulmaktadır.

\section{Geçerlik ve güvenirlik bulguları}

Ölçeğin geçerlik çalışmaları için öncelikle kapsam geçerliğini belirlemek amacıyla alan uzmanlarından görüş alınmıştır. Uzmanlar, geliştirilen maddeleri anlaşılabilirlik, ölçülmek istenen davranışı yansıtabilirlik ve gelişimsel uygunluk açılarından değerlendirmiştir. Verilen görüşler doğrultusunda gerekli düzenlemeler yapılmıştır. Her yaş grubuna farklı olarak hazırlanan formlar, uzman görüşleri doğrultusunda birleştirilerek tek bir forma indirgenmiştir.

69 madde olarak hazırlanan bu form üzerinden ikinci kez uzman görüşü alınmıştır. $\mathrm{Bu}$ görüşler sırasında madde sayısında bir değişiklik olmamıştır.

Ölçeğin yapı geçerliliğini incelemek için önce, verilerin faktör analizi için uygun yapıda olup olmadığı belirlenmiştir. Tablo 2'de dönüştürülmüş temel bileşenler analizi sonuçları verilmiştir:

Tablo 2

KMO ve Bartlett Testi Sonuçları

\begin{tabular}{|r|l|}
\hline Kaiser-Meyer-Olkin Measure of Sampling Adequacy & .901 \\
\hline Bartlett's Test of Sphericity Approx. Chi-Square & 9098.528 \\
\hline df & 1485 \\
\hline Sig & .000 \\
\hline
\end{tabular}

KMO değeri, verilerin faktör çıkarmak için uygun olup olmadığına karar vermenin bir ölçüsü olarak kullanılmaktadır. Bu değerin yüksek olması ölçekteki her bir değişkenin, diğer değişkenler tarafından mükemmel bir şekilde tahmin edilebileceği anlamına gelmektedir (Şencan, 2005; Tavşanc1l, 2005). KMO değeri incelendiğinde örneklem büyüklüğünün .60 değerinden yüksek olması nedeniyle faktör analizi için oldukça yeterli olduğu görülmüş ve $p($ sign. $)=0.000<0.05$ olduğundan Barlett Testi manidar çıkmıştır. Değişkenler arasında yüksek korelasyon bulunmakta ve normallik varsayımı karşılanmaktadır. Faktör analizi sonuçlarına göre birinci aşamada 14, ikinci aşamada 6, üçüncü aşamada 3 olmak üzere toplam 23 madde ölçekten çıkartılmıştır. 
Serpilme diyagramında, özdeğeri bir ve birden fazla olan dört faktör olduğundan bu dört faktör seçilmiştir. Açıklanan toplam varyans, dönüşümden önceki ve sonraki özdeğerleri vermekte ve dört faktörün çıtığını göstermektedir. Birinci faktör toplam varyansın \%16.022'sini, ikinci faktör \%13.813’ünü, üçüncü faktör \%10.116’sını, dördüncü faktör \%9.034’ünü açıklamaktadır. Özdeğerlerin açıkladığı birikimli varyans miktarı, toplam varyansın \%48.985’idir. Açıklanan varyans değerlerine ve serpilme diyagramına bakılarak, dört faktörlü yapıda karar kılınmıştır. Yapılan analizler sonucunda ölçeğin, 46 maddeden ve dört faktörden oluştuğu görülmektedir. Dönüşümlü faktör yükleri ve faktörlerdeki maddelerin içerdikleri anlam dikkate alınarak; birinci faktöre giyinme-soyunma, ikinci faktöre tertip-düzen, üçüncü faktöre yemek yeme, dördüncü faktöre kişisel temizlik-tuvalet başılıları verilmiştir.

Şekil 1'de normallik değerlerine ilişkin serpilme diyagramı yer almaktadır.

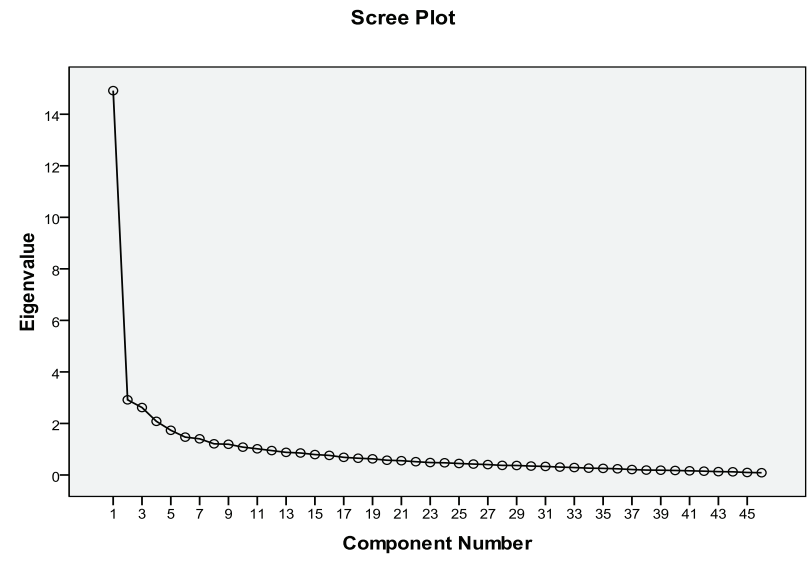

Şekil I. Serpilme Diyagramı

Maddelerin yer aldıkları faktörlerdeki yük değerleri ve madde toplam korelasyonları incelenmiş ve aşağıdaki değerler arasında olduğu bulunmuştur.

Tablo 3

Maddelerin Faktör Yük Değerleri ve Madde Toplam Korelâsyonları

\begin{tabular}{|l|c|c|}
\hline \multicolumn{1}{|c|}{ Faktör } & Madde Faktör Yük Değerleri & Madde Toplam Korelâsyonları \\
\hline 1. Giyinme-soyunma & $.724-.521$ & $.738-.552$ \\
\hline 2. Tertip-düzen & $.721-.485$ & $.730-.487$ \\
\hline 3. Yemek yeme & $.740-.504$ & $.703-.472$ \\
\hline 4. Kişisel temizlik-tuvalet & $.601-.431$ & $.567-.426$ \\
\hline
\end{tabular}


Faktörlerdeki yük değerlerinin yüksek olduğu görülmektedir. Madde toplam korelasyon değerlerinin .30'dan yüksek olması maddeler arasındaki ilişkilerin yüksek olduğunun göstergesidir (Büyüköztürk, 2013).

Ölçeğin güvenirlik analizleri her faktör için ayrı ayrı ve ölçeğin tamamı için yapılmıştır. Tablo 4’te güvenirlik katsayıları sunulmaktadır.

Tablo 4

Faktörlere Göre Cronbach Alfa Güvenirlik Katsayıları

\begin{tabular}{|l|c|c|}
\hline \multicolumn{1}{|c|}{ Faktör } & $\boldsymbol{a}$ & Madde Sayıs \\
\hline 1.Giyinme-soyunma & .93 & 14 \\
\hline 2.Tertip-düzen & .89 & 14 \\
\hline 3.Yemek yeme & .86 & 9 \\
\hline 4.Kişisel temizlik-tuvalet & .79 & 9 \\
\hline
\end{tabular}

Ölçeğin bütünü için yapılan güvenirlik analizinde ise cronbach alfa güvenirlik katsayısı 95 olarak bulunmuştur. Bu değer, ölçme aracındaki maddelerin kendi aralarında tutarlılık gösterip göstermediğini test etmek amacıyla kullanılmaktadır. Güvenirlik katsayısı 0 ile 1 arasında değişmekte ve bu değer l'e yaklaştıkça güvenirlik artmaktadır (Ural ve Kılıç, 2006).

Analizler sonucunda ortaya çıkan bu değerler incelendiğinde, “Okul Öncesi Dönem Çocukları (36-72 ay) İçin Özbakım Becerileri Ölçeği-Öğretmen Formu”nun özbakım becerilerini ölçmek için geçerli ve güvenilir bir araç olduğu belirlenmiştir.

\section{Önemlilik durumuna yönelik bulgular}

Çalışmaya katılan öğretmenlerin ölçekte yer alan maddeleri önemli bulma durumları incelenmiştir. Önem durumu incelenirken “önemli değil”, “önemli” ve “çok önemli” ifadeleri kullanılmıştır.Öğretmenleraraştırmagrubundabulunançocuklarıbireyselolarakdeğerlendirmiştir. Örneklemde yer alan 585 çocuğun verileri önem boyutuna göre gözden geçirilmiş, 10 ve daha fazla sayıda maddesi doldurulmayan çocukların verileri çıkartılmıştır. Sonuç olarak öğretmenlerin maddeleri önemli bulma durumu 479 çocuk üzerinden değerlendirilmiştir. Tablo 5 'te maddelerin önem sıraları verilmiştir. 
Marmara Üniversitesi Atatürk Eğitim Fakültesi Eğitim Bilimleri Dergisi • Journal of Educational Sciences Yll: Ocak $2017 \cdot$ Cilt-Sayı $45 \cdot$ ISSN: I300-8889 • ss. 59-78

Tablo 5

Maddelerin Önem Sıraları.

\begin{tabular}{|c|c|c|c|c|c|c|c|c|c|}
\hline \multirow[b]{2}{*}{ Madde } & \multicolumn{2}{|c|}{ Çok Önemli } & \multicolumn{2}{|c|}{ Önemli } & \multicolumn{2}{|c|}{ Önemli Değil } & \multicolumn{2}{|c|}{ Belirtilmemiş } & \multirow[b]{2}{*}{ Toplam } \\
\hline & $\mathrm{F}$ & $\%$ & $\mathrm{~F}$ & $\%$ & $\mathbf{F}$ & $\%$ & $\mathrm{f}$ & $\%$ & \\
\hline 49 & 267 & 55.74 & 181 & 37.79 & 31 & 6.47 & 0 & 0.00 & 479 \\
\hline 53 & 261 & 54.49 & 191 & 39.87 & 25 & 5.22 & 2 & 0.42 & 479 \\
\hline 54 & 249 & 51.98 & 193 & 40.29 & 30 & 6.26 & 7 & 1.46 & 479 \\
\hline 39 & 239 & 49.90 & 216 & 45.09 & 24 & 5.01 & 0 & 0.00 & 479 \\
\hline 51 & 235 & 49.06 & 214 & 44.68 & 30 & 6.26 & 0 & 0.00 & 479 \\
\hline 48 & 233 & 48.64 & 213 & 44.47 & 27 & 5.64 & 6 & 1.25 & 479 \\
\hline 45 & 224 & 46.76 & 213 & 44.47 & 39 & 8.14 & 3 & 0.63 & 479 \\
\hline 40 & 222 & 46.35 & 231 & 48.23 & 24 & 5.01 & 2 & 0.42 & 479 \\
\hline 5 & 216 & 45.09 & 241 & 50.31 & 21 & 4.38 & 1 & 0.21 & 479 \\
\hline 52 & 216 & 45.09 & 235 & 49.06 & 24 & 5.01 & 4 & 0.84 & 479 \\
\hline 18 & 209 & 43.63 & 241 & 50.31 & 28 & 5.85 & 1 & 0.21 & 479 \\
\hline 55 & 209 & 43.63 & 245 & 51.15 & 25 & 5.22 & 0 & 0.00 & 479 \\
\hline 17 & 205 & 42.80 & 242 & 50.52 & 28 & 5.85 & 4 & 0.84 & 479 \\
\hline 1 & 200 & 41.75 & 215 & 44.89 & 27 & 5.64 & 37 & 7.72 & 479 \\
\hline 19 & 198 & 41.34 & 249 & 51.98 & 31 & 6.47 & 1 & 0.21 & 479 \\
\hline 38 & 194 & 40.50 & 263 & 54.91 & 21 & 4.38 & 1 & 0.21 & 479 \\
\hline 12 & 192 & 40.08 & 252 & 52.61 & 32 & 6.68 & 3 & 0.63 & 479 \\
\hline 34 & 192 & 40.08 & 257 & 53.65 & 24 & 5.01 & 6 & 1.25 & 479 \\
\hline 31 & 190 & 39.67 & 263 & 54.91 & 25 & 5.22 & 1 & 0.21 & 479 \\
\hline 9 & 189 & 39.46 & 256 & 53.44 & 34 & 7.10 & 0 & 0.00 & 479 \\
\hline 36 & 189 & 39.46 & 268 & 55.95 & 20 & 4.18 & 2 & 0.42 & 479 \\
\hline 59 & 188 & 39.25 & 261 & 54.49 & 28 & 5.85 & 2 & 0.42 & 479 \\
\hline 30 & 187 & 39.04 & 256 & 53.44 & 31 & 6.47 & 5 & 1.04 & 479 \\
\hline 20 & 186 & 38.83 & 259 & 54.07 & 32 & 6.68 & 2 & 0.42 & 479 \\
\hline 23 & 182 & 38.00 & 268 & 55.95 & 27 & 5.64 & 2 & 0.42 & 479 \\
\hline 25 & 181 & 37.79 & 263 & 54.91 & 34 & 7.10 & 1 & 0.21 & 479 \\
\hline 33 & 181 & 37.79 & 257 & 53.65 & 34 & 7.10 & 7 & 1.46 & 479 \\
\hline 58 & 181 & 37.79 & 269 & 56.16 & 26 & 5.43 & 3 & 0.63 & 479 \\
\hline 24 & 178 & 37.16 & 260 & 54.28 & 40 & 8.35 & 1 & 0.21 & 479 \\
\hline 37 & 178 & 37.16 & 268 & 55.95 & 32 & 6.68 & 1 & 0.21 & 479 \\
\hline 15 & 177 & 36.95 & 261 & 54.49 & 36 & 7.52 & 5 & 1.04 & 479 \\
\hline 57 & 176 & 36.74 & 259 & 54.07 & 41 & 8.56 & 3 & 0.63 & 479 \\
\hline 4 & 170 & 35.49 & 274 & 57.20 & 30 & 6.26 & 5 & 1.04 & 479 \\
\hline 35 & 170 & 35.49 & 275 & 57.41 & 33 & 6.89 & 1 & 0.21 & 479 \\
\hline 29 & 168 & 35.07 & 267 & 55.74 & 35 & 7.31 & 9 & 1.88 & 479 \\
\hline 10 & 167 & 34.86 & 272 & 56.78 & 39 & 8.14 & 1 & 0.21 & 479 \\
\hline 26 & 166 & 34.66 & 281 & 58.66 & 30 & 6.26 & 2 & 0.42 & 479 \\
\hline 3 & 163 & 34.03 & 276 & 57.62 & 37 & 7.72 & 3 & 0.63 & 479 \\
\hline 14 & 162 & 33.82 & 275 & 57.41 & 35 & 7.31 & 7 & 1.46 & 479 \\
\hline 6 & 159 & 33.19 & 272 & 56.78 & 36 & 7.52 & 12 & 2.51 & 479 \\
\hline 22 & 159 & 33.19 & 295 & 61.59 & 24 & 5.01 & 1 & 0.21 & 479 \\
\hline 21 & 152 & 31.73 & 284 & 59.29 & 39 & 8.14 & 4 & 0.84 & 479 \\
\hline 8 & 151 & 31.52 & 281 & 58.66 & 37 & 7.72 & 10 & 2.09 & 479 \\
\hline 27 & 150 & 31.32 & 277 & 57.83 & 49 & 10.23 & 3 & 0.63 & 479 \\
\hline 7 & 139 & 29.02 & 280 & 58.46 & 46 & 9.60 & 14 & 2.92 & 479 \\
\hline 61 & 132 & 27.56 & 251 & 52.40 & 32 & 6.68 & 64 & 13.36 & 479 \\
\hline
\end{tabular}


En önemli bulunan ilk üç maddenin "Tuvalete gitmesi gerektiğini hissedip zamanında tuvalete gider", "Tuvalet ihtiyacın giderdikten sonra ellerini sabunla yıkar" ve "Tuvalete gitmesi gerektiğinde uykusundan uyanıp tuvalete gider" olduğu belirlenmiştir. Genel olarak bakıldığında "kişisel temizlik-tuvalet" başlıklı dördüncü boyutta yer alan maddelerin en önemli bulunan maddeler olduğu görülmektedir.

Diğerlerine oranla daha az "çok önemli" bulunan son üç madde ise "Mont, hırka vb. giysilerin fermuarını yardım almadan alt kısmını geçirerek kapatır", "Servis tabağından katı yiyecekleri dökmeden başkasına uzatır” ve "Giysilerini gerektiğinde (düştüğünde, etkinlik sonrasında vb.) çırparak/ silkeleyerek temizler" şeklindedir.

\section{Değișkenlere yönelik bulgular}

Özbakım becerilerinin değişkenlere göre değerlendirilmesi 261 form üzerinden gerçekleştirilmiştir. Belirlenen değişkenlere yönelik analiz yöntemine karar vermek amacıyla dağılımın normalliği incelenmiştir. Şekil 2'de ve Tablo 6'da dağılımın normalliğine ilişkin veriler aktarılmıştır.

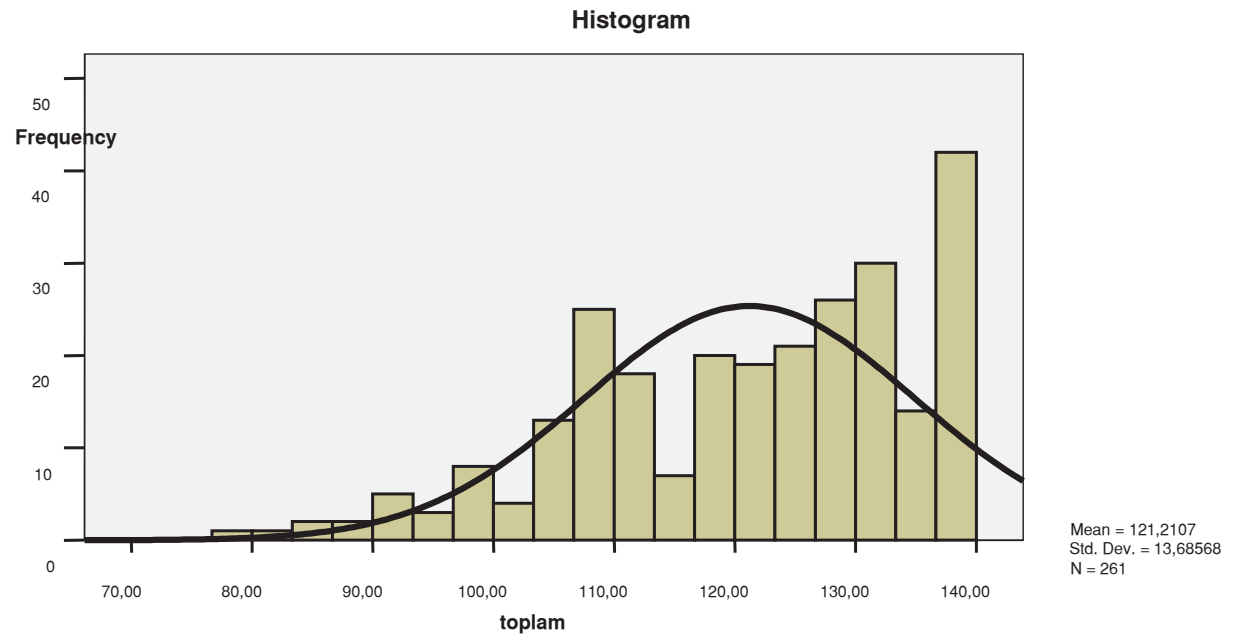

Şekil 2. 46 madde ve 261 kişi için dağılım normalliğini gösteren histogram grafiği.

Tablo 6

Normallik testi sonuçları.

\begin{tabular}{|c|c|c|c|c|c|c|}
\hline \multirow{2}{*}{} & \multicolumn{3}{|c|}{ Kolmogorov-Smirnov(a) } & \multicolumn{3}{c|}{ Shapiro-Wilk } \\
\cline { 2 - 7 } & Statistic & df & Sig. & Statistic & df & Sig. \\
\hline Toplam & .110 & 261 & .000 & .932 & 261 & .000 \\
\hline
\end{tabular}


Histogram ve normallik testi göz önüne alındığında dağılımın normal olmadığ anlaşılmaktadır. Bu nedenle nonparametrik analizler yapılmıştır.

Özbakım becerilerinin cinsiyete göre farklılık gösterip göstermediğinin incelenmesi için Mann Whitney-U Testi uygulanmıştır.

Tablo 7

Özbakım becerilerinin cinsiyete göre Mann Whitney-U Testi Sonuçları

\begin{tabular}{|r|c|c|c|c|c|}
\hline \multicolumn{1}{|c|}{ Cinsiyet } & N & Sira ortalamasi & Sira Toplamı & U & p \\
\hline $\begin{array}{r}\text { Erkek } \\
\text { Kız }\end{array}$ & 136 & 130.31 & 17722.50 & & \\
\cline { 2 - 4 } Toplam & 125 & 131.75 & 16468.50 & 8406.5 & .878 \\
\cline { 2 - 2 } & 261 & & & & \\
\hline
\end{tabular}

Tablo 7’de görülebileceği gibi erkek ve kız çocuklarının özbakım becerileri arasında anlamlı farklılık bulunmamıştır.

Özbakım becerilerinin belirlenen ay aralıklarına göre farklılık gösterip göstermediğinin incelenmesi için Kruskall Wallis Testi yapılmıştır.

Tablo 8

Özbakım becerilerinin ay aralıklarına göre Kruskall Wallis Testi sonuçlan

\begin{tabular}{|c|c|c|c|c|c|}
\hline Ay aralıkları & $\mathrm{N}$ & $\begin{array}{c}\text { Sira } \\
\text { Ortalamaları }\end{array}$ & sd & K-kare & $\mathbf{P}$ \\
\hline $36-41$ & 9 & 82.44 & \multirow{7}{*}{5} & \multirow{7}{*}{11.65} & \multirow{7}{*}{.040} \\
\hline $42-47$ & 19 & 93.95 & & & \\
\hline $48-53$ & 38 & 121.12 & & & \\
\hline 54-59 & 62 & 144.58 & & & \\
\hline $60-65$ & 72 & 137.65 & & & \\
\hline $66-72$ & 61 & \multirow[t]{2}{*}{134.20} & & & \\
\hline Toplam & 261 & & & & \\
\hline
\end{tabular}

Kruskall Wallis Testine göre .05 düzeyinde gruplar arasında anlamlı fark bulunmuştur. Farkın hangi gruplar arasında olduğunu belirlemek için Mann Whitney-U Testi uygulanmıştır. 
Tablo 9

Özbakım becerilerinin ay aralıklarına göre Mann Whitney-U Testi sonuçları.

\begin{tabular}{|c|c|c|c|c|c|c|}
\hline \multicolumn{2}{|c|}{ Gruplar } & Fark & Sira Ortalaması & Sira Toplamı & U & P \\
\hline \multirow{4}{*}{$36-41$} & $42-47$ & Yok & 13.94 & 14.76 & 80.50 & .809 \\
\cline { 2 - 7 } & $48-53$ & Yok & 19.50 & 25.07 & 130.50 & .279 \\
\cline { 2 - 7 } & $54-59$ & Var & 21.72 & 38.07 & 150.50 & .026 \\
\cline { 2 - 7 } & $60-65$ & Var & 24.22 & 43.10 & 173.00 & .023 \\
\cline { 2 - 7 } & $66-72$ & Var & 23.06 & 37.34 & 162.50 & .049 \\
\hline \multirow{4}{4}{$42-47$} & $48-53$ & Yok & 25.50 & 30.75 & 294.50 & .259 \\
\cline { 2 - 7 } & $54-59$ & Var & 29.47 & 44.53 & 370.00 & .015 \\
\cline { 2 - 7 } & $60-65$ & Var & 33.42 & 49.32 & 445.00 & .019 \\
\cline { 2 - 7 } & $66-72$ & Var & 30.79 & 43.52 & 395.00 & .037 \\
\hline \multirow{4}{48-53}{} & $54-59$ & Yok & 45.66 & 53.47 & 994.00 & .191 \\
\cline { 2 - 7 } & $60-65$ & Yok & 50.61 & 58.08 & 1182.00 & .242 \\
\cline { 2 - 7 } & $66-72$ & Yok & 47.04 & 51.84 & 1046.50 & .417 \\
\hline \multirow{2}{*}{$\mathbf{5 4 - 5 9}$} & $60-65$ & Yok & 69.90 & 65.44 & 2083.50 & .507 \\
\cline { 2 - 7 } & $66-72$ & Yok & 64.61 & 59.34 & 1729 & .412 \\
\hline $\mathbf{6 0 - 6 5}$ & $66-72$ & Yok & 67.72 & 66.16 & 2144.50 & .816 \\
\hline
\end{tabular}

Tablo 9'da görülebileceği gibi, 36-41 ay aralığında yer alan çocukların sıra ortalamaları 5459, 60-65 ve 66-72 aylık çocuklara oranla daha azdır. Buna paralel olarak, 42-47 ay aralığında yer alan çocukların sıra ortalamaları 54-59, 60-65 ve 66-72 aylık çocukların sıra ortalamalarından daha düşüktür. Bu durum özbakım becerilerinde yaşın büyümesinin etkili olduğu sonucunu ortaya çıkarmaktadır.

Özbakım becerileri üzerinde etkili olabileceği düşünülen bir durum da çocukların doğum sıralarıdır. Böyle bir farkın var olup olmadığını belirlemek için Mann Whitney-U Testi uygulanmıştır.

Tablo 10

Özbakım becerilerinin doğum sırasına göre Mann Whitney-U Testi sonuçları

\begin{tabular}{|r|c|c|c|c|c|}
\hline Doğum sırası & $\mathbf{n}$ & Sıra Ortalamaları & sd & K-kare & P \\
\hline Birinci & 178 & 126.30 & & & \\
\hline İkinci & 26 & 153.21 & \multirow{2}{*}{2} & 3.58 & .166 \\
\hline Üçüncü ve sonra & 51 & 121.09 & & & \\
\hline Toplam & 255 & & & & \\
\hline
\end{tabular}

Tablodan da görülebildiği gibi çocukların doğum sıraları arasında anlamlı bir farklılık bulunmamaktadır. Aileler çocuklarının özbakım becerileri söz konusu olduğunda doğum sırasına göre herhangi bir ayrım yapmamaktadırlar. 
Marmara Üniversitesi Atatürk Eğitim Fakültesi Eğitim Bilimleri Dergisi • Journal of Educational Sciences

Yll: Ocak $2017 \cdot$ Cilt-Sayı $45 \cdot$ ISSN: I300-8889 • ss. 59-78

Doğum sırasının özbakım becerileri üzerindeki durumu belirlenirken merak edilen bir diğer benzer nokta da kardeşi olma durumudur.

Tablo 11

Özbakım becerilerinin kardeşi olup olmama durumuna göre Mann Whitney-U Testi sonuçları

\begin{tabular}{|c|c|c|c|c|c|}
\hline Kardeş & $\mathbf{n}$ & Sira ortalaması & Sira Toplamı & $\mathrm{U}$ & $\mathbf{P}$ \\
\hline Var & 127 & 134.48 & 17078.50 & \multirow{3}{*}{7178.5} & \multirow{3}{*}{.130} \\
\hline Yok & 127 & 120.52 & 15306.50 & & \\
\hline Toplam & 254 & & & & \\
\hline
\end{tabular}

Kardeşi olma ve olmama durumunun özbakım becerileri üzerinde anlamlı bir fark yaratmadığı bulunmuştur. Bu sonuç bir önceki tablo sonuçları ile paralellik göstermektedir.

Özbakım becerileri okul öncesi eğitim kurumları tarafından da desteklenen ve önemsenen becerilerin başında yer almaktadır. Bu nedenle okul öncesi eğitim alma süresinin özbakım becerileri üzerinde etkili olma durumu incelenmiștir.

Tablo 12

Özbakım becerilerinin eğitim alma süresine göre Kruskall Wallis Testi sonuçları

\begin{tabular}{|c|c|c|c|c|c|}
\hline Eğitim Alma Süresi & N & Sira Ortalamaları & sd & K-kare & P \\
\hline Bir yıldan az & 143 & 114.91 & & & \\
\cline { 1 - 3 } $\mathbf{1 - 2}$ yıl & 85 & 143.30 & \multirow{2}{*}{2} & 10.954 & .004 \\
\hline 2-3 yıl & 18 & 98.28 & & & \\
\hline Toplam & 245 & & & & \\
\hline
\end{tabular}

Kruskall Wallis Testine göre .05 düzeyinde gruplar arasında anlamlı fark bulunmaktadır. Farkın hangi gruplar arasında olduğunu belirlemek için Mann Whitney-U Testi uygulanmıştır.

Tablo 13

Özbakım becerilerinin okul öncesi eğitim alma süresine göre Mann Whitney-U Testi sonuçları

\begin{tabular}{|c|c|c|c|c|c|c|}
\hline \multicolumn{2}{|c|}{ Gruplar } & Fark & Sira ortalamas & Sira Toplamı & U & p \\
\hline \multirow{2}{*}{$\mathbf{1}$ yıldan az } & $1-2$ yll & Var & 104.80 & 130.82 & 4690.00 & .004 \\
\cline { 2 - 7 } & $2-3$ yll & Yok & 82.11 & 72.19 & 1128.50 & .395 \\
\hline \multirow{2}{*}{$\mathbf{1 - 2}$ yll } & $2-3$ yll & Var & 55.48 & 35.58 & 469.50 & .010 \\
\hline
\end{tabular}


Okul öncesi eğitim kurumlarına 1 yıldan az bir süre ve 1-2 yıl devam eden çocukların özbakım becerileri arasında, bu kurumlara daha fazla devam eden çocuklar lehine anlamlı fark olduğu görülmüştür. Bir diğer anlamlı farklılık da okul öncesi eğitim kurumlarına 1-2 yıl ve 2-3 yıl devam eden çocukların özbakım becerileri arasında, kurumlara 2-3 yıl devam eden çocuklar lehine bulunmuştur. Ancak bu farkın bir önceki gruba göre daha az olduğu belirlenmiştir. Okul öncesi eğitim alma süresinin artması özbakım becerileri üzerinde olumlu etkiye sahiptir.

Okul öncesi eğitim alma süresine ek olarak akla gelen bir durum da çocukların bu kurumlara yarım gün ya da tam gün devam etme durumlarıdır. Devam süresinin özbakım becerileri üzerinde etkili olup olmadığını belirlemek için Mann Whitney-U Testi yapılmıştır.

Tablo 14

Özbakım becerilerinin okul öncesi eğitim kurumlarına devam süresine göre Mann Whitney-U Testi sonuçları

\begin{tabular}{|c|c|c|c|c|c|}
\hline Devam süresi & $\mathbf{n}$ & Sıra ortalaması & Sıra Toplamı & U & P \\
\hline Tam gün & 195 & 125.18 & 24410.00 & & \\
\cline { 2 - 4 } $\begin{array}{c}\text { Yarım gün } \\
\text { Toplam }\end{array}$ & 53 & 122.00 & 6466.00 & \multirow{2}{*}{5035.0} & .775 \\
\cline { 2 - 2 } & 248 & & & & \\
\hline
\end{tabular}

Tablo 14’te de görüldüğü gibi çocukların okul öncesi eğitim kurumlarına tam ya da yarım gün devam etmelerinin özbakım becerileri üzerinde anlamlı bir fark yaratmadığı belirlenmiştir.

\section{Tartışma}

Yapılan analizler sonucunda, "Okul Öncesi Dönem Çocukları (36-72 ay) İçin Özbakım Becerileri Ölçeği-Öğretmen Formu"nun geçerli ve güvenilir bir araç olduğu bulunmuştur. Öğretmenlerin ölçeğin dördüncü boyutunda yer alan "Kişisel temizlik-tuvalet" maddelerini diğerlerine oranla çok daha önemli buldukları görülmüştür.

Erkek ve kız çocuklarının özbakım becerileri arasında anlamlı farklılık bulunmamıştır. Demirtaş่ın (2001) yapmış olduğu çalışmada da, özbakım ve bazı temel beceriler açısından çocukların cinsiyetine göre anlamlı bir fark olmadığı görülmüştür. Aynı şekilde Demiriz ve Dinçer tarafından 2001 yılında yapılan araştırmada beş-altı yaş çocuklarının özbakım becerileri cinsiyete göre karşılaştırıldığında da anlamlı fark bulunmamıştır.

Ailelerin çocuk yetiştirmeye ilişkin deneyimleri, çeşitli alanlardaki tutumlarında farklılıklara yol açabilmektedir. Özbakım becerilerini kazandırmada da bu tür bir farklılı̆̆ın olup olmadığı bu araştırmada incelenen diğer bir değişkendir. Elde edilen bulgulara göre, çocukların doğum sırasının özbakım becerileri üzerinde anlamlı bir farklılığa yol açmadığı görülmüştür. Demirtaş’ın (2001) araştırmasında da, doğum sırasına göre yapılan değerlendirme sonuçlarına bakıldığında özbakım becerileri yönünden anlamlı bir farklılığa rastlanmamıştır. 
Okul öncesi eğitimin sistemli ve etkili bir şekilde yürütülmesi sonucunda, çocuğun bütün gelişim alanlarında sahip olduğu beceriler olumlu yönde gelişmekte ve bu becerilere yenileri eklenmektedir. Hem evde hem de okulda yaşama geçirilmesi desteklenen özbakım becerileri de bu gelişimin açılkça gözlemlenebileceği davranışları içerir. Demiriz ve Dinçer (2001), beşaltı yaş çocuklarının özbakım becerilerini cinsiyet değişkenin yanı sıra okul öncesi eğitim alma durumlarına göre de ele almış ve okul öncesi eğitimi alan çocukların almayan çocuklara göre özbakım becerilerinin daha fazla geliştiği görülmüştür. Bu bulgu yapılan araştırma sonucu ile tutarlılık göstermektedir.

Bulgularda görüldüğü gibi, okul öncesi eğitim alma süresinin artması özbakım becerileri üzerinde olumlu etkiye sahiptir. Çocukların yaşları büyüdükçe ve eğitim alma süreleri arttıkça özbakım becerilerini hayata geçirme oranları artmaktadır. Bu da çocukların yarım ya da tam gün, aile olanakları ne olursa olsun mutlaka bir kuruma devam etmeleri gerektiğini göstermektedir. Aynı şekilde Yalçın, Başar ve Çetinkaya (2013) yaptıkları araştırmada, okul öncesi eğitime üçdört yaşında başlayan çocukların özbakım beceri düzeylerinin okul öncesi eğitime beş-altı yaşında başlayan çocuklara göre daha gelişmiş olduğu, özbakım beceri düzeyinin okul öncesi eğitime başlama yaşı ile ilişkili olduğu sonucuna ulaşılmışlardır.

Araşıırma sonucuna dayalı olarak; Okul Öncesi Dönem Çocukları (36-72 ay) İçin Özbakım Becerileri Ölçeği kullanılarak çok daha geniş örneklemler ile özbakım becerilerine ilişkin normlar belirlenmesi ve her yaşa ait özbakım becerileri ayrıntılı olarak ayrı ayrı incelenmesi önerilebilir. Olumsuz yaşam koşullarında olan ve herhangi bir eğitim desteği alamayan çocukların özbakım becerilerinin belirlenmesi için okul öncesi eğitim kurumuna devam etmeyen çocukların özbakım becerileri de incelenmeli ve ihtiyaca yönelik eğitim programları geliştirilmelidir. Hazırlanan bu ölçek öğretmen görüşlerine dayanmaktadır. Daha güvenilir değerlendirmeler yapabilmek için farklı yöntem ve araçlar kullanılarak, her bir alt boyuta ilişkin olarak gözlem listeleri hazırlanabilir. Çocukların özbakım becerileri hem öğretmenler hem de aileler tarafından dikkatlice gözlemlenebilir. Saçkes (2013) anne-babalar ve okul öncesi öğretmenlerinin okul öncesi eğitim programında hedeflenen gelişimsel alanların öncelikleri hakkındaki görüşlerini ve görüşleri arasındaki tutarlılığ incelemek amacıyla bir çalışma yapmıştır. Bilişsel gelişim, özbakım becerileri, sosyal ve duygusal gelişim ve dil gelişimi alanlarındaki becerilerin geliştirilmesine yönelik anne ve babalar ile öğretmenler arasında uyum olduğu bulunmuş, bunun nedeninin programın hedeflediği gelişim alanlarının anne ve babalarca evde de desteklenme olasılı̆̆ının yüksek olabileceği belirtilmiştir.

Özbakım becerileri tüm beceriler gibi ancak uygulama yapılarak kalıcı olabilmektedir. $\mathrm{Bu}$ nedenle gerek kurumlarda gerekse ev ortamında çocuklara ihtiyaç duydukları firsatlar yaratılmalıdır. Bu fırsatlar fiziksel düzenlemelerin yanı sıra etkinlikleri de kapsamalıdır.

Çocukların yaşları büyüdükçe giysi seçimleri hakkında daha çok söz sahibi olmaları sağlanmalıdır. Mevsime uygun giyinme becerisi ilk başlarda özellikle ebeveynleri zorlayan durumlara yol açsa da, çocukların denemelerine izin verilen pek çok farklı fırsatın sağlanması ile geliştirilebilir. Çocukların bedenleri üzerinde hâkimiyetleri arttıkça hareketleri daha kontrollü 
ve amaçlı olabilir. Çok küçük çocuklar dahi fırsat verildiğinde kendi giysilerini çıkarabilirler. Yaş büyüdükçe sadece giysileri çıkarmakla kalmazlar aynı zamanda kendi kendilerine giyinmeye de başlarlar. Önceleri giysilerin ön-arka ve ters-düz özelliklerini karıştırabilirler. Ancak kısa zamanda pek çok defa yapılan tekrarlar sayesinde bu özellikleri de ayırt edebilirler. Yetişkinler kolay giyilip çıkarılabilen giysileri kullanarak oyun aracılığı ile çocukların giysilerini doğru şekilde giymelerini sağlayabilirler. Varol ve Civitci (2010) ve Boğday Sayğılı (2014) tarafından yapılan araştırmalarda kız ve erkek çocuklarının giysi tercihleri incelenmiş, çocukların giysilerini giyerken yaşadıkları zorluklar incelenerek bu becerinin daha kolay uygulanmasını sağlayıcı giysi tasarımları önerilmiştir.

Çocuğun gerek evdeki odasını gerekse okul öncesi eğitim kurumunda kendisine ayrılan bir bölme varsa bu alanı düzenli tutabilmesi için öğretmenler ve ebeveynler tarafından çocuklara firsatlar verilmelidir. Çocuğun boyuna uygun elbise askıları, çekmeceler ve dolap bölmeleri ayarlanmalıdır. Temiz ve kirli çamaşırlarını nasıl ayıracağı, nereye koyacağı ve nasıl düzenleyeceği konuları çocukla birebir zaman geçirilerek anlatılmalıdır. Giysilerin yanı sıra oyuncak ve kitaplarını koyacağı da özel bölmeler olmalı ve çocuk bu düzene alıştırılmalıdır. Çocuğun oluşturulan bu düzeni kendi kendine devam ettirmesini sağlamak için çekmecelerin ve dolapların kapaklarına içinde nelerin yer aldığına dair resimler yapıştırılabilir. İçi görünen kutular ya da sepetler sayesinde çocuk oyuncaklarını ya da boya kalemlerini rahatça toparlayabilir.

Okul öncesi eğitim kurumlarında yemek ya da kahvaltı zamanları belirli saatler arasında ve genel olarak bütün çocuklarla birlikte gerçekleştirilmektedir. Evde de yemek için belirli zaman aralıklarının belirlenmesi ve sofraya hep birlikte oturulup kalkılması önerilmektedir. Yemek öncesi ve sonrası temizlik hem hijyen koşullarını sağlamak hem de çocuğa örnek olması açısından bütün bireyler tarafından gerçekleştirilmelidir. Tüketilecek yiyecek ve içeceklerin özellikleri ne olursa olsun, ortamın temizliği ve düzenine çok önem verilmelidir. Bu durumun gerekliliği ve önemi çocuklara özellikle her seferinde hissettirilmelidir. Çocuklar, sofranın kurulmasından kaldırılma aşamasına kadar etkin olarak sorumluluk almalıdırlar. Bunun yanı sıra çocuğun yaşı büyüdükçe yiyecek ve içecekleri hazırlama konusunda da katılımları sağlanmalıdır.

Çocuğa uygun lavabo ve tuvaletlerin bulunması, bu durum sağlanamadı̆̆ı takdirde çocuğun bunlara ulaşabilmesinin sağlanması için hem evde hem de kurumlarda gerekli düzenleme yapılmalıdır. Yine çocuğun boyu ile uygun ölçüde havlu asacaklarının olması, muslukların, sabun, diş macunu, diş firçası ve tuvalet kâğıdının yerleşiminin çocuğa göre ayarlanması, bu yapılamadığ takdirde çocuğun kendi başına gereksinimlerini gidermesi için alınacak önlemlerin belirlenmesi gerekmektedir. Özellikle banyo zemininin ve yere serilen malzemelerin kaymaması için ek önlemler alınması gerekebilir. Genellikle evlerin banyolarındaki dolaplarda saklanan çamaşır suyu, yumuşatıcı ve bunun gibi tehlikeli maddelerin çocukların ulaşamayacağı yerlere alınması gerekmektedir. Tüm bu düzenlemeler hem önlemler alınarak çocuklara yetişkinler tarafından bu fırsatların verilmesini hem de çocukların özbakım becerilerini kendilerinin yerine getirmesini sağlayacaktır. 


\section{Kaynaklar}

Akşin, E., ve Tunçeli, H. İ. (2015). Okul öncesi dönem çocuklarının" tehlike" kavramına ilişkin görüşleri. Hacettepe University Faculty of Health Sciences Journal, (1), s.599-609.

Bekem, Ö., Öztürk, Y., Arslan, N. ve Büyükgebiz, B. (2003). İştahsız çocuklarda beslenme özelliklerinin anket çalışması ile değerlendirilmesi. Dokuz Eylül Tip Fakültesi Dergisi (1), 181-91.

Boğday Sayğıllı, B. (2014) Okul öncesi çocukların giyinme davranışlarını geliştirmeye yönelik giysi tasarımı. NWSA: Vocational Education 9 (3), 50-59.

Büyüköztürk, Ş. (2013). Sosyal bilimler için veri analizi el kitabı. 18. Baskı. Ankara: PegemA .

Büyüköztürk, Ş., Çakmak, E. K., Akgün, Ö. E., Karadeniz, Ş. ve Demirel, F. (2010) Bilimsel araştırma yöntemleri. Ankara: PegemA.

Chiarello, L. A., Palisano, R. J., Bartlett, D. J. ve McCoy, S. W. (2011). A multivariate model of determinants of change in gross-motor abilities and engagement in self-care and play of young children with cerebral palsy.Physical ve occupational therapy in pediatrics, 31(2), 150-168.

Creswell , J. W. (2013). Araştırma deseni: nicel, nitel ve karma yöntem yaklaşımları. (Çev. Ed. S. B. DEMİR). Ankara: Eğiten Kitap.

Demirtaş, K. (2001). Annelerin değerlendirmesine göre çocukların özbakım becerileri ile anne tutumları arasındaki ilişki. Yayınlanmamış Yüksek Lisans Tezi, Marmara Üniversitesi, Eğitim Bilimleri Enstitüsü, İstanbul.

Demiriz, S. ve Dinçer, Ç. (2000). Dönem çocuklarının özbakım becerilerinin annelerinin çalışıp çalışmama durumlarına göre incelenmesi. Hacettepe Üniversitesi Eğitim Fakültesi Dergisi, (19), 58-65.

Demiriz, S. ve Dinçer, Ç. (2001). 5-6 Yaş çocuklarının özbakım becerilerinin cinsiyet ve okul öncesi eğitim alma durumlarına göre incelenmesi. Milli Eğitim Dergisi, s.150, 11-19.

Frank, K., ve Esbensen, A. J. (2015). Fine motor and self-care milestones for individuals with Down syndrome using a Retrospective Chart Review. Journal of Intellectual Disability Research, 59(8), 719-729.

Gazezoğlu, Ö. (2007). Okul öncesi eğitim kurumlarına devam eden 6 yaş çocuklarına özbakım becerilerinin kazandırlmasında oyun yoluyla öğretimin etkisi. Yüksek Lisans Tezi. Dokuz Eylül Üniversitesi Eğitim Bilimleri Enstitüsü. İzmir.

Geiger, B. F., Artz, L., Petri, C. J., Winnail, S. D., ve Mason, J. W. (2000). "Fun with Handwashing Education”. ERIC: ED4447335.

Goldstein, R. (2006). Ana babalık sanatı (Çeviren N. Önol). İstanbul: Özgür.

Jasmin, E., Couture, M., McKinley, P., Reid, G., Fombonne, E., ve Gisel, E. (2009). Sensori-motor and daily living skills of preschool children with autism spectrum disorders. Journal of autism and developmental disorders, 39(2), 231-241.

Katz, L.G. (1999). “Another look at what young children should be Learning”, Databases/ ERIC: ED453980.

Kelo, M., Martikainen, M., ve Eriksson, E. (2011). Self-care of school-age children with diabetes: an integrative review. Journal of advanced nursing,67(10), 2096-2108.

Ketelaar, M., Gorter, J. W., Westers, P., Hanna, S., ve Verhoef, M. (2014). Developmental trajectories of mobility and self-care capabilities in young children with cerebral palsy. The Journal of pediatrics, 164(4), 769-774.

Konya, S. (2007). Kubaşık öğrenme etkinliklerinin beşyaş grubu öğrencilerinin özbakım becerilerinin gelişimine etkisi. Yüksek Lisans Tezi. Adnan Menderes Üniversitesi. Sosyal Bilimler Enstitüsü. Aydın.

Kruijsen-Terpstra, A. J., Ketelaar, M., Verschuren, O., Gorter, J. W., Vos, R. C., Verheijden, J., Ongmans, M., ve Visser-Meily, A. (2015). Efficacy of three therapy approaches in preschool children with cerebral palsy: a randomized controlled trial. Developmental Medicine ve Child Neurology. 
MEB, 2013. MEB okul öncesi eğitim programı, Ankara: Milli Eğitim Bakanlığı.

Oktay, A. (2004). Yaşamın sihirli yılları. İstanbul: Epsilon.

Oktay, A. (2005). Okul öncesi eğitimin önemi ve yaygınlaştırılması. Okul öncesi eğitimde güncel konular. Derleyen: Oktay. A, Unutkan, Ö. P. İstanbul: Morpa, 11-24.

Önder, A. (2003). Okul öncesi çocukları için eğitici drama uygulamaları. İstanbul: Morpa.

Özdamar, K. (2013). Modern bilimsel araştırma yöntemleri. Eskişehir: Kaan.

Saçkes, M. (2013). Erken çocukluk eğitiminde önem verilmesi gereken gelişimsel alanlar: anne-baba ve öğretmen önceliklerinin karşılaştırılması. Kuram ve Uygulamada Eğitim Bilimleri Dergisi, 13(3), 1675-1690.

Senemoğlu, N. (2008). Gelişim öğrenme ve öğretim. Ankara: Gazi.

Şencan, H. (2005). Sosyal ve davranışsal ölçümlerde güvenilirlik ve geçerlilik. Ankara: Seçkin.

Tavşancıl, E. (2005). Tutumların ölçülmesi ve spss ile veri analizi. Ankara: Nobel.

Temiz, G., ve Girgin Büyükbayraktar, Ç. (2014). The Relationship between the Self-Care Skills of Children Attending Preschool and Perfectionisms of Their Mothers. Middle Eastern ve African Journal of Educational Research, Issue 11 Year 2014, 4-25.

Ural, A. ve Kılıç, İ. (2006). Bilimsel araștırma süreci ve SPSS ile veri analizi; SPSS 10.0-12.0 for Windows. (2. Bask1) Ankara: Detay, 281-294.

Ünver, Y. (2004). 5-6 yaş okul öncesi dönemi çocukları için geliştirilecek besin gruplarına yönelik beslenme eğitimi programlarının çocukların beslenme bilgileri ve davranışlarına etkisi. Yüksek Lisans Tezi, Selçuk Üniversitesi, Sosyal Bilimler Enstitüsü.

Ünver, Y. ve Ünüsan, N. (2005). Okul öncesinde Beslenme Eğitimi Üzerine Bir Araştırma. Selçuk Üniversitesi Sosyal Bilimler Dergisi, S. 14, s. 529-551.

Varol, N. (2005). Beceri öğretimi ve özbakım becerilerinin kazandırılması. Ankara: Kök.

Varol, E. ve Çivitci, S. (2010). Okul öncesi çocukların giyinme becerilerini kolaylaştırmaya yönelik giysi tasarımları. NWSA: Vocational Education, 5(1), 1-16.

Yalçın, M., Başar, M. ve Çetinkaya, A. (2013). Okul öncesi eğitime 5-6 yaşında başlayan çocuklar ile 3-4 yaşında başlayan çocukların özbakım becerilerinin veli görüşlerine göre incelenmesi (Uşak İli Örneği). Uşak Üniversitesi Sosyal Bilimler Dergisi,(16), 208-244. 